\title{
Gallbladder Undifferentiated Carcinoma, Spindle and Giant Cell Type
}

National Cancer Institute

\section{Source}

National Cancer Institute. Gallbladder Undifferentiated Carcinoma, Spindle and Giant Cell

Type. NCI Thesaurus. Code C5838.

An undifferentiated carcinoma that arises from the gallbladder. It is characterized by the presence of spindle and giant malignant cells, including osteoclast-like giant cells. 